\title{
Ichthyophonus infection in grey mullets from Southern Africa: histopathological and ultrastructural study
}

\author{
Ilan Paperna
}

Department of Animal Sciences, Faculty of Agriculture of the Hebrew University of Jerusalem, Rehovot 76-100, Israel

\begin{abstract}
Heavy infection with Ichthyophonus in the viscera and gills was revealed in 2 out of 86 examined grey mullets (Mugilidae) from Kowie lagoon, SE Cape province. Spores in the viscera were enclosed either by a epitheloid granuloma or by a fibrous capsule. In the gills, spores infected the filament as well as the lamellae; spores invaded the lamellae via the capillaries. Walls of the large multinucleate spores consisted of longitudinally compressed microfibrils, superimposed by deposits of the host's cellular residues. This wall developed from a thin wall consisting of a non-fibrous electron dense layer of the small uninucleate spores. Spore endoplasm contained a variety of organelles, most of which occur also in phycomycete fungi. Nevertheless the revealed fine structure of the large multinucleate as well as the small uni and binucleate spores do not provide supportive evidence for the taxonomic position of Ichthyophonus among the fungi.
\end{abstract}

\section{INTRODUCTION}

Ichthyophonus infections have been reported from a number of species of marine fish from the north Atlantic region (Ruggieri et al. 1970, Neish \& Hughes 1980, McVicar 1982) and more recently from Japan (Chien et al. 1979). Feeding cultured fish on unprocessed marine fish extended infection with this pathogen into cultured fish in both marine and freshwater farms (Gustafson \& Rucker 1956, Doriere \& Degrange 1961, Miyazaki \& Kubota 1977). Machado-Cruz et al. (1982) reported widespread infection by Ichthyophonus (using its synonym Ichthyosporidium) in grey mullets Mugil cephalus and Liza aurata (reported as Mugil auratus) from Portugal. So far, in spite of several elaborate studies on its parasite life cycle (Daniel 1933, Dorier \& Degrange 1961, Okamoto et al. 1985), there is still no conclusive evidence as to the relation of Ichthyophonus with other groups of fungi (Neish \& Hughes 1980, Alderman 1982, McVicar 1982). Electron microscopic studies of Ichthyophonus are presently limited to a few preliminary reports: of Alderman (1982) describing multinucleate spores, where each nucleus is accompanied by a Golgi apparatus, mitochondria and endoplasmic reticulum; of McVicar (1982) and McVicar \& McLay (1985) emphasising the relation of the parasitic fungus to its host cells and tissue; and of Okamoto et al. (1985) describing several stages from in vitro culture.

\section{MATERIALS AND METHODS}

Samples of tissues from infected grey mullets were taken for light microscope (LM) histology and transmission electron microscopy (TEM). These samples were taken within 3 min after the fish had been killed (by decapitation) and after confirmation of infection by LM examination of fresh squash impressions of gill or kidney tissue. For LM histology, tissue fragments were fixed in $10 \%$ buffered neutral formalin and embedded in glycol methacrylate by Lulham (1979) methodology. Sections, $3 \mu \mathrm{m}$ thick, cut by Sorval JB4 glass knife microtome, were stained in Meyer's hematoxylin eosin (HE) or in Hematoxylin-PAS (H-PAS) method.

For TEM, tissue fragments were fixed in $3 \%$ glutaraldehyde in buffer cacodylate, $0.1 \mathrm{M}, \mathrm{pH} 7.4$, for $24 \mathrm{~h}$ at $4{ }^{\circ} \mathrm{C}$. After intensive rinsing in the same buffer, tissue was post-fixed in $1 \%$ osmium tetraoxide in the same buffer for $1 \mathrm{~h}$ in room temperature. After subsequent rinse, tissue was dehydrated in ascending alcohols and embedded in Epon. Thin sections cut by 


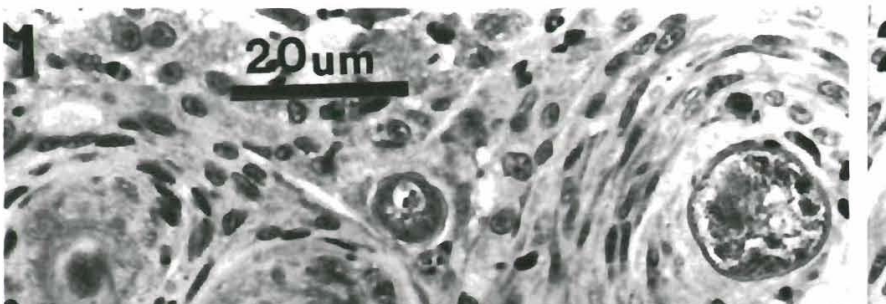

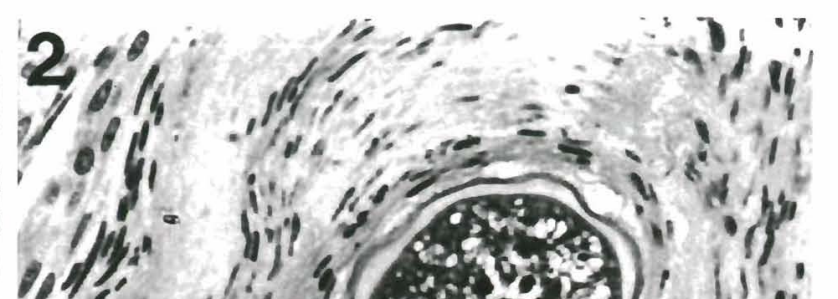

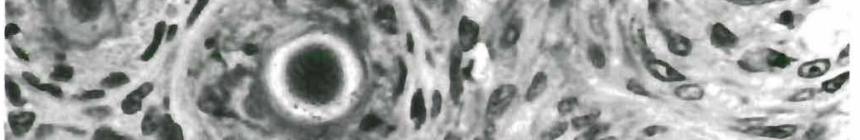

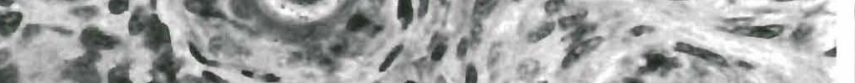

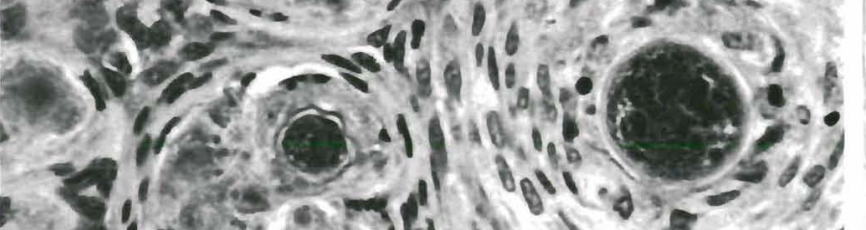

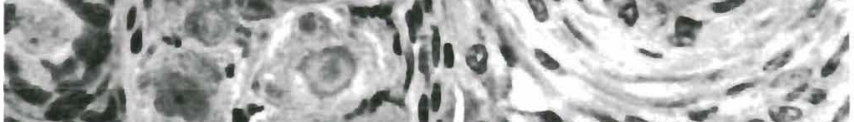

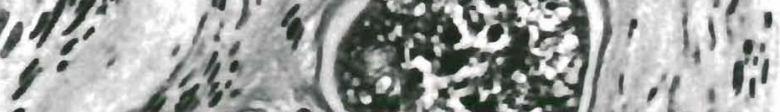

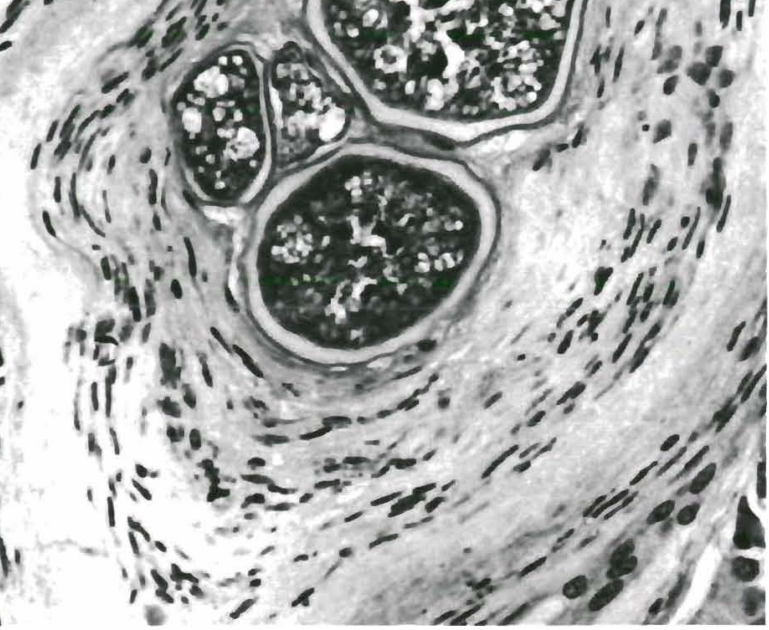

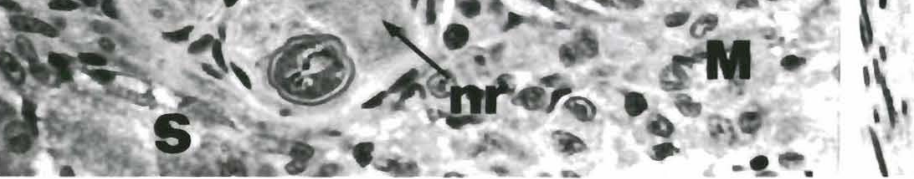

$3 x-5,8$
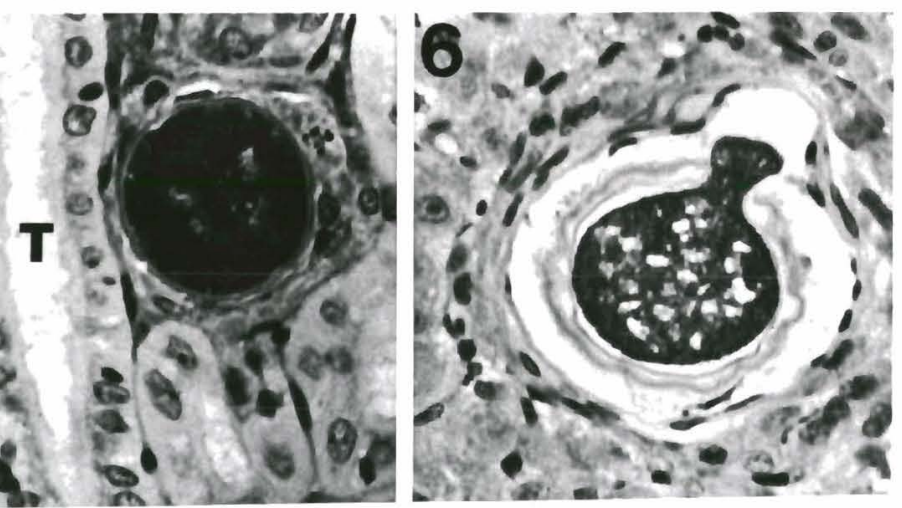

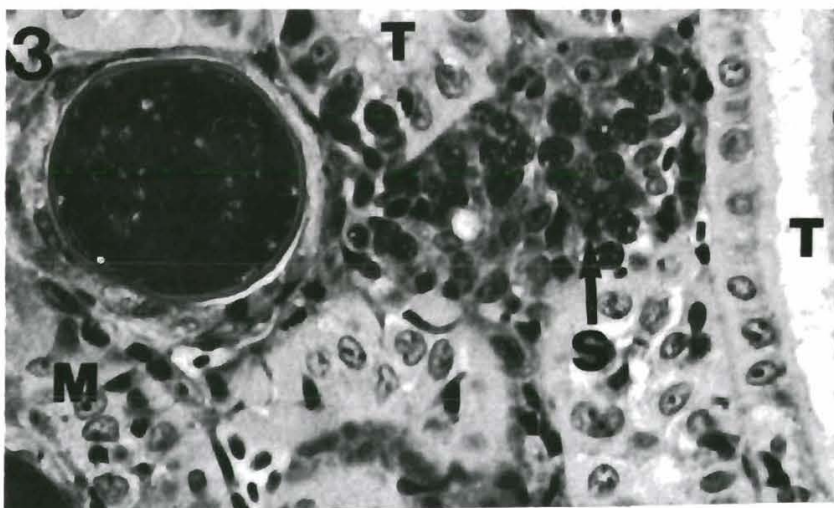

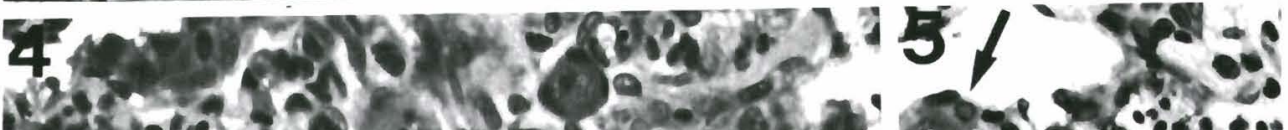

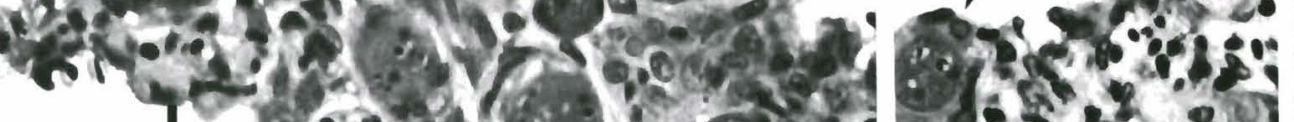
150 s.

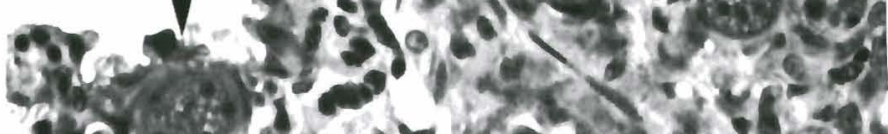

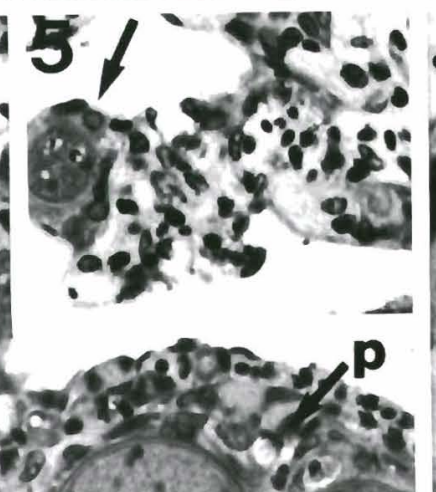

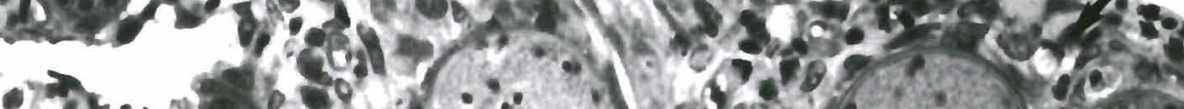

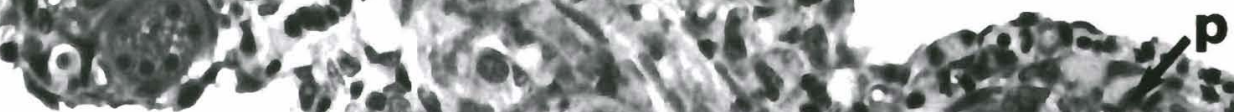

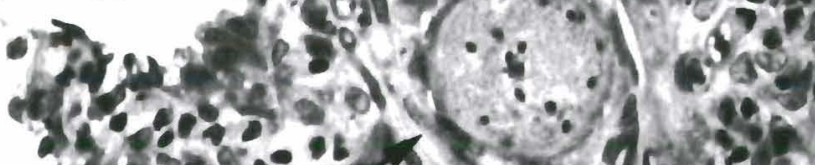

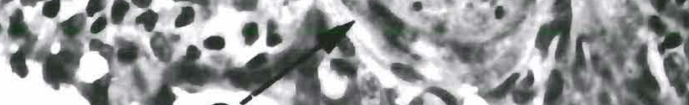

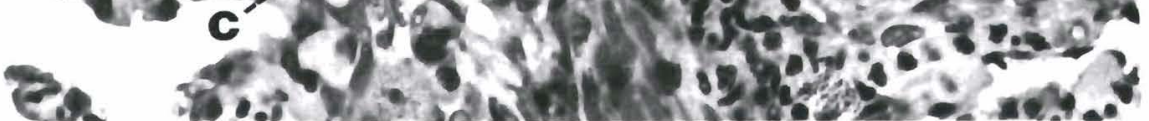

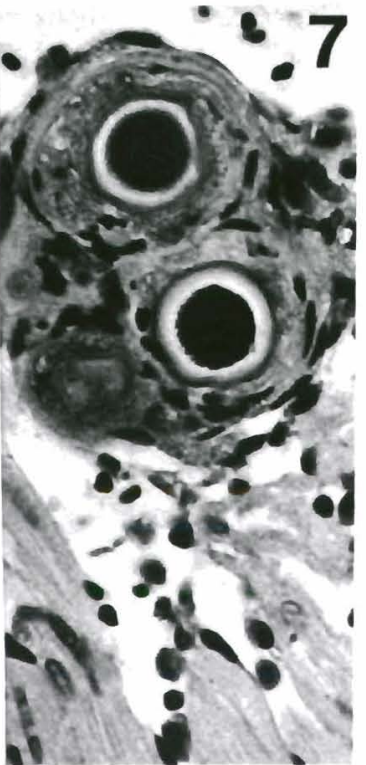


LKBIII ultratome with diamond knife were stained on the grid with aqueous uranyl acetate and lead citrate and examined in a TEMSCAN 100CX II TEM.

\section{RESULTS}

\section{Hosts, locality and prevalence}

Examination of grey mullets (Mugilidae) from Kowie lagoon, located on the southeastern shore of Cape Province, Republic of South Africa (in July 1984, at water salinities of $32 \mathrm{ppt}$ ) revealed extremely heavy infection in 2 fish (Mutil cephalus, $112 \mathrm{~mm}$ long and Liza sp., $55 \mathrm{~mm}$ long), while all the remaining 84 fish examined ( 35 to $200 \mathrm{~mm}$ long) were free from infection (Table 1).

Table 1. Records of infection prevalence by Ichthyophonus in grey mullets (Mugilidae) caught in July 1984 from Kowie lagoon

\begin{tabular}{|rcl|}
\hline \multicolumn{1}{|c|}{ Size class } & No. neg. & No. pos. \\
\hline$<50 \mathrm{~mm}$ & 21 & 0 \\
$51-80 \mathrm{~mm}$ & 5 & 1 (Liza sp.) \\
$81-100 \mathrm{~mm}$ & 8 & 0 \\
$101-150 \mathrm{~mm}$ & 26 & 1 (M. cephalus) \\
$>151 \mathrm{~mm}$ & 24 & 0 \\
\hline
\end{tabular}

\section{Light microscopy}

Spores ('resting spores') were distributed in the organs of both fish in a similar pattern. Both fish were heavily infected, with the highest concentrations of spores in the liver (Fig. 1 \& 2), the spleen, the kidney (Fig. 3) and the gills (Fig. 4). Spores in moderate to small numbers were seen in the gut wall, muscles, myocardium (Fig. 7), wall of the gall bladder and in the exocrine pancreas. Few germinating spores were found in the liver, the intestinal wall and the heart. Large multinucleate spores ( $>15 \mu \mathrm{m}$ in diameter, vide M-spores) enclosed in a thick PAS positive wall, occurred either singly or in small groups (Fig. 1, 2 \& 3); small, uni, or binucleate spores $(<9 \mu \mathrm{m}$ in diameter, vide $\mathrm{S}$-spores), enclosed in a thin PAS positive wall occured in clumps, often close to the M-spore (Fig. 1 \& 3).

M-spores were enclosed either by epitheloid (granulomatous tissue) or by fibrous layers of variable density ranging from a thin layer of fibroblasts (Fig. 1, $6 \& 7$ ) to a thick fibrous capsule (Fig. 2). Epitheloid and fibroblast layers also occurred intermittently around many M-spores. Cellular residue and necrotic (PAS positive) substance (ground substance) often accumulated between the $\mathrm{M}$-spore perimeter and either the epitheloid or the fibrous layers (Fig. 2). In heavily infected sectors of tissue a common necrotic zone was formed around spore aggregates (Fig. 1). In heavily infected gills, both the filaments and the lamellae were infected and consequently deformed (Fig. 4, 5). Inflammatory infiltration was very limited and deformations resulted either directly due to the pressure effect of the spores in the organ or due to subsequently induced epithelial proliferation. Spores were found both in the connective tissue core (including the perichondrium) and in the epithelial layer of the filament. In the epithelium spores were sometimes enclosed by a thin layer of fibroblasts, which hinted at their primary location in the connective tissue layer. In some cases of epithelial proliferation, the cells adjacent to the spore were degenerated, swollen, hydropic or vacuolate; in other cases spores were embedded in a necrotic matrix. In the lamellae, spores emerged from the capillaries, thus displacing both the endothelium and the lamellar epithelium (Fig. 4 \& 5), but they rarely induced cellular proliferation. Spores were often embedded in a necrotic or hyaline matrix. S-spores were seen free in the lumen of the capillaries of the filament and the lamellae.

In the muscles, including those of the heart, spores were located in the connective tissue component. In the somatic muscles spores were usually surrounded by loose aggregates of fibroblasts and macrophages, while in the heart they were enclosed by a distinct fibrous capsule (Fig. 7). Germinating hyphae were seen penetrating through the fibrous capsule (Fig. 6).

Fig. 1 to 7. Light micrographs. Fig. 1. M-spores and S-spores in the liver, host tissue response around M-spores in transition from epitheloid to encapsulation by fibroblasts, S-spores are embedded in necrotic matrix (HE). Fig. 2. M-spores in the liver, enclosed in fibrous capsule (HE). Fig. 3. M-spores with adjacent aggregates of S-spores in the trunk kidney, tissue response around the spores is limited to few macrophages (H-PAS). Fig. 4. Infection in the gills, the spore in the lamella (arrow) is embedded in hyalin matrix, spores in the filament are encased in fibroblasts (c), spores in the interlamellar are enclosed by proliferated epithelium (p) (HE). Fig. 5. Spore in the gill lamella (HE). Fig. 6. Germinating spore in the liver (H-PAS). Fig. 7. Encapsulated spores in the myocardium, note thickening and degradation of the spore wall (H-PAS)

Abbreviations for figures. A: carbohydrate storage granules; $\mathrm{A}^{\prime}$ : small carbohydrate storage granules; b: dense bodies; bi: initial stage dense bodies; bd: developing dense bodies; c: fibroblasts; d: deposited layer of host cell residues; dv: double membrane bound vesicles; $\mathrm{H}$ : host cell; L: lipid vacuole; Lm: lomasome; M: M-spores; m: mitochondria; mt: membranous body; N: nucleus; nl: nucleolemma; nr: necrotic substance; p: proliferated epithelium; pl: plasmalemma; S: S-spores; sp: vesicles between the wall and the plasmalemma; T: kidney tubules; t: endoplasmic tubules; v: multivesicular vacuole; W: spore wall 


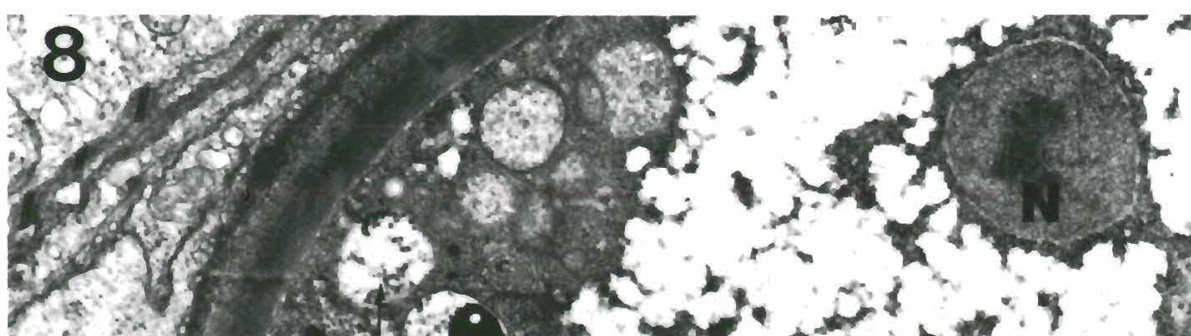

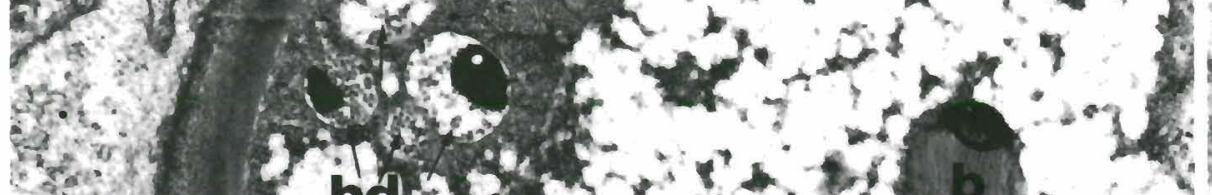

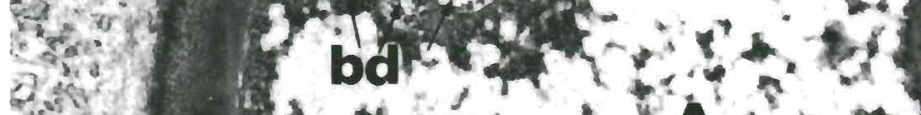

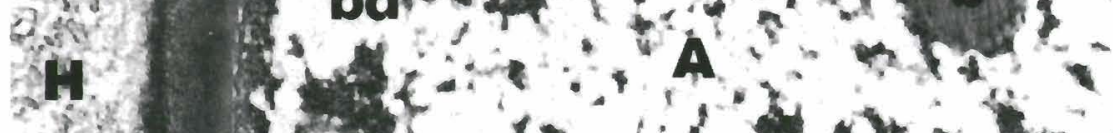

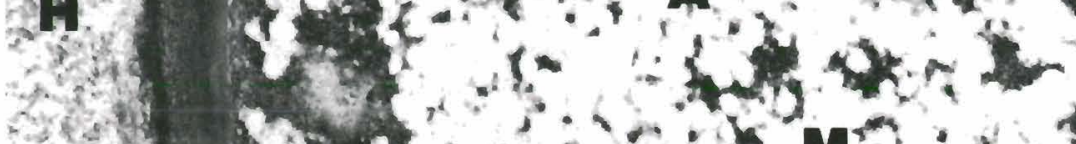

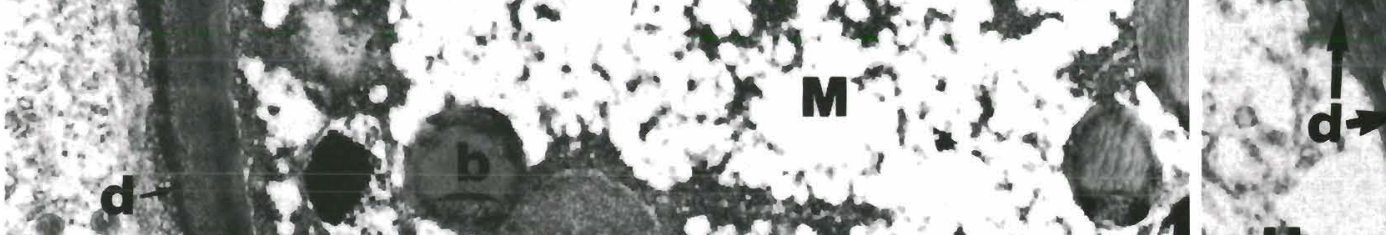

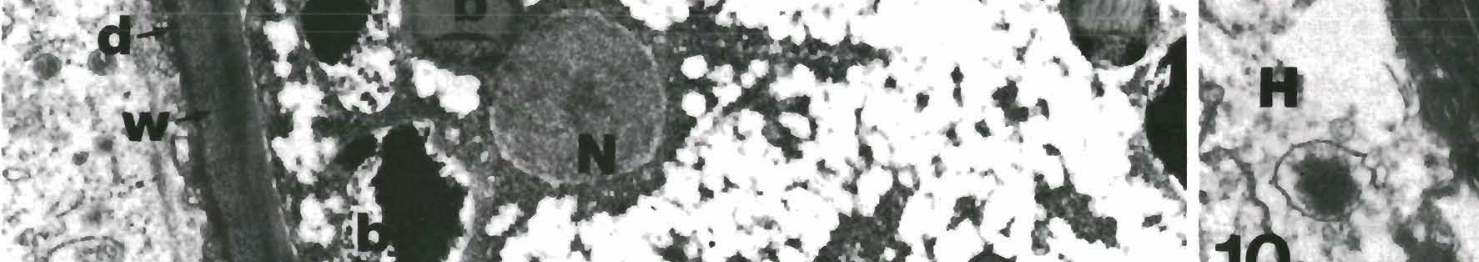

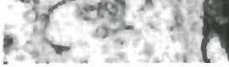

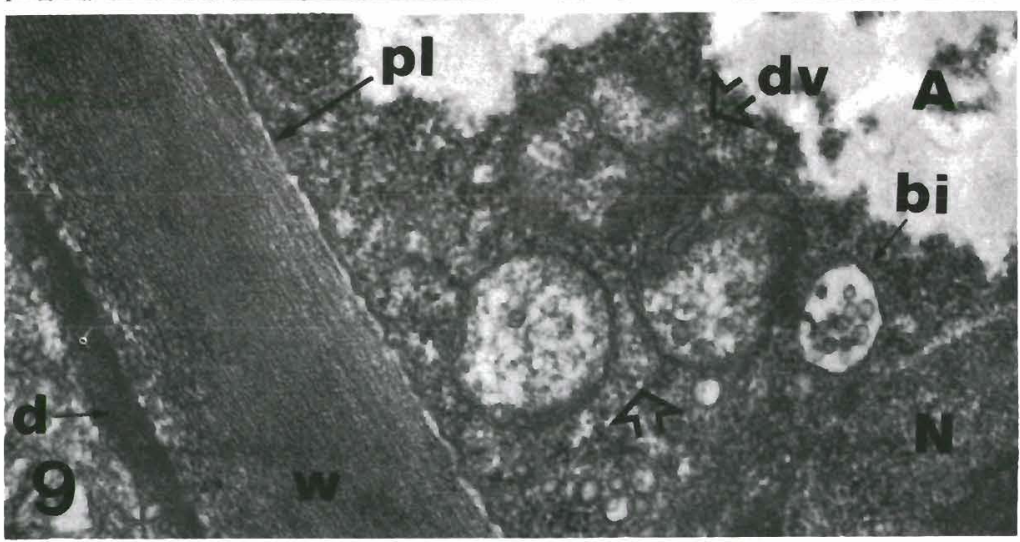

pi 1 dy of
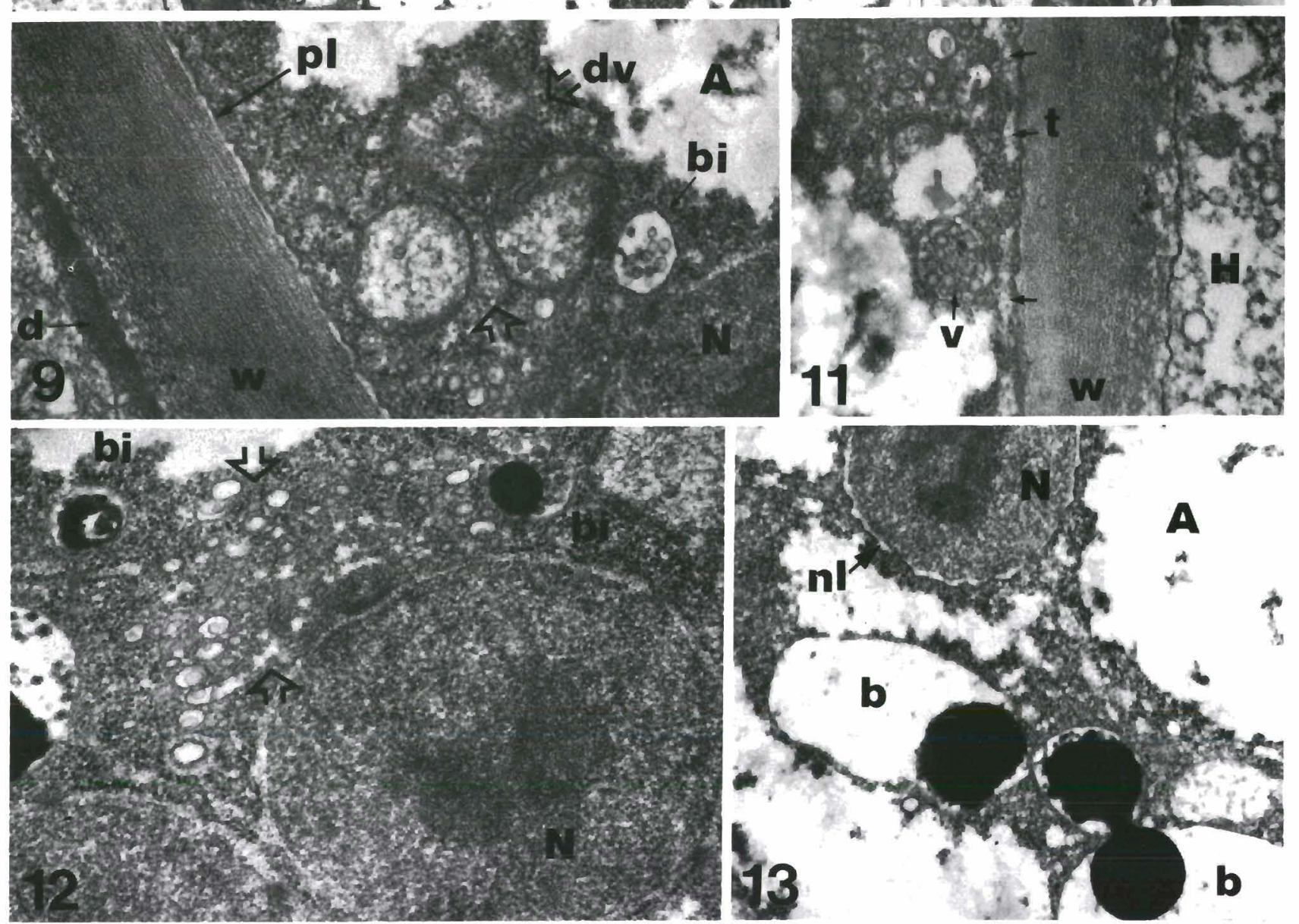


\section{Electron microscopy}

\section{M-spores}

M-spores, 15 to $23 \mu \mathrm{m}$ in diameter (Fig. 8) were enclosed by a thick, 0.5 to $0.7 \mu \mathrm{m}$ wall consisting of longitudinally compressed microfibrils. The central layer was usually more compressed than the inner layer (Fig. $9 \& 10$ ). Near the surface, the fibrous layers were gradualy degrading and loosing their stratified organization (Fig. $9 \& 11$ ). The outer layers of the spore wall were merging with a superimposed layer of dense amorphous substance (Fig. 8, 9 \& 14) which often also contained residues of the host cells. This outer layer was of variable thickness, density and consistency and in some instances contained distinct remnants of the host cell nuclei and organelles (Fig. 10 \& 15).

An increase in wall thickness, along with apparent reduction of the endoplasm volume was seen in material studied both by LM (Fig. 2 \& 7) and TEM (Fig. 15). In this process (which appears to be of a degenerative nature), there was an apparent loss of the fibrillar configuration of the wall (evident in LM by a loss of the eosinophilic staining properties).

The endoplasm was delineated from the wall by a distinct bilaminated plasmalemma (Fig. 9). Few to fair number of vesicles were found compressed between the plasmalemma and the wall.

The endoplasm consisted of a fine granulated matrix perfused with numerous ribosomes and contained several nuclei. In most nuclei the nucleolus and the nucleolemma were clearly seen (Fig. 12). The entire volume of the endoplasm except for a narrow paramural and perinuclear zones was packed with globular electron-lucent bodies (carbohydrate storage substance, PAS positive in LM) (Fig. 8, 14 \& 15). The endoplasm also contained a number of large dense body vesicles; the latter either contained a large electron-dense body or were empty (Fig. 8, 13 \& 15). Vacuoles containing lipids were only occasionally seen.

The paramural endoplasm contained a distinct tubular system (Fig. 11). Lomasomes were seen only in few instances (Fig. 16). The perinuclear endoplasm contained a complex of dictyosomes and small vesicles apparently derived from the dictyosomes (Fig. 12 \& 17), multivesicular vacuoles (Fig. $11 \& 16$ ), as well as vesicles bound by a double membrane or 2 bilaminated membranes which contained flocculent substance and membrane residues (Fig. 9). The latter could have been damaged mitochondria - distinctly definable mitochondria were not seen in M-spores. Dense bodies appeared to originate from small vacuoles, bound by a single unit membrane containing globules or small vesicles (Fig. $9 \&$ 17). These vacuoles also become filled with electron dense particles (Fig. 12). These particles were gradually condensating into larger electron-dense bodies as these vacuoles increased in size (Fig. $8 \& 15$ ).

\section{Early stage spores (S-spores)}

The smallest observed spores ('endospores') were 4 to $6 \mu \mathrm{m}$ in diameter and enclosed by a 50 to $140 \mathrm{~nm}$ thick wall, these early spores revealed only 1 nucleus in cross section (Fig. 18). Larger spores (usually spherical in cross section, 6.5 to $8.2 \times 4.6$ to $5.1 \mu \mathrm{m}$ in size) revealed 2 nuclei per section (Fig. 19). S-spore wall was gradually formed from an initial 50 to $70 \mathrm{~nm}$ thick layer of an amorphous, finely granulated electron dense matrix, which incorporated a few discontinuous microfibril strands (Fig. 20). Thicker walls (of 70 to $100 \mathrm{~nm}$ ) already consisted of several (2 to 5) fibrillar strands which were heavily deposited with electrondense granular matrix (Fig. $19 \& 24$ ). Spore walls (100 to $400 \mathrm{~nm}$ thick) consisted of multiple layers of microfibrils identical to that seen in the M-spores (Fig. 25).

Host cellular residues already accumulated on the periphery of the spores from an early stage in their development (Fig. 18). This fact, as well as disruptions in the host tissue bordering the spore, obscured the actual relation between the spores and the host tissue. In a few instances, where the induced damage was less severe, the interface between the parasite and its host substrate suggested an initial intracellular location for the young spore (Fig. 22 \& 24). Spores, otherwise, were located intercellularily, embedded in dense cellular residue.

Stages in the spore wall differentiation did not always correspond with the increase in the size of the $\mathrm{S}$-spore (in cross sections). Thus, thick (>130 nm) multilayered fibrous walls were already seen in S-spores 5 to $6 \mu \mathrm{m}$ in diameter (in cross section). The measured diameter of spore cross sections may, however, be biased by the section plane and may not correspond with its actual size. The endoplasm was delineated by undulating plasmalemma (Fig. 20). A few vesicles occurred between the plasmalemma and the wall (Fig. 22). The electron-lucent globules (the presumed carbohydrate granules) were either absent, or if present were small and in limited numbers (Fig. 19 \& 24). Several large lipid or electron-lucent vacuoles occur-

Fig. 8 to 13. Transmission electron micrographs. Fig. 8. M-spore $(\times 12,450)$. Fig. 9 to 11. Spore wall, outer layer of host cell origin and organelles of the paramural endoplasm $(9: \times 36,500 ; 10: \times 14,600 ; 11: \times 40,600)$. Fig. 12. Perinuclear endoplasm. Arrows: dictyosomes and associated vesicles $(\times 38,000)$. Fig. 13 . Dense bodies $(\times 17,000)$ 

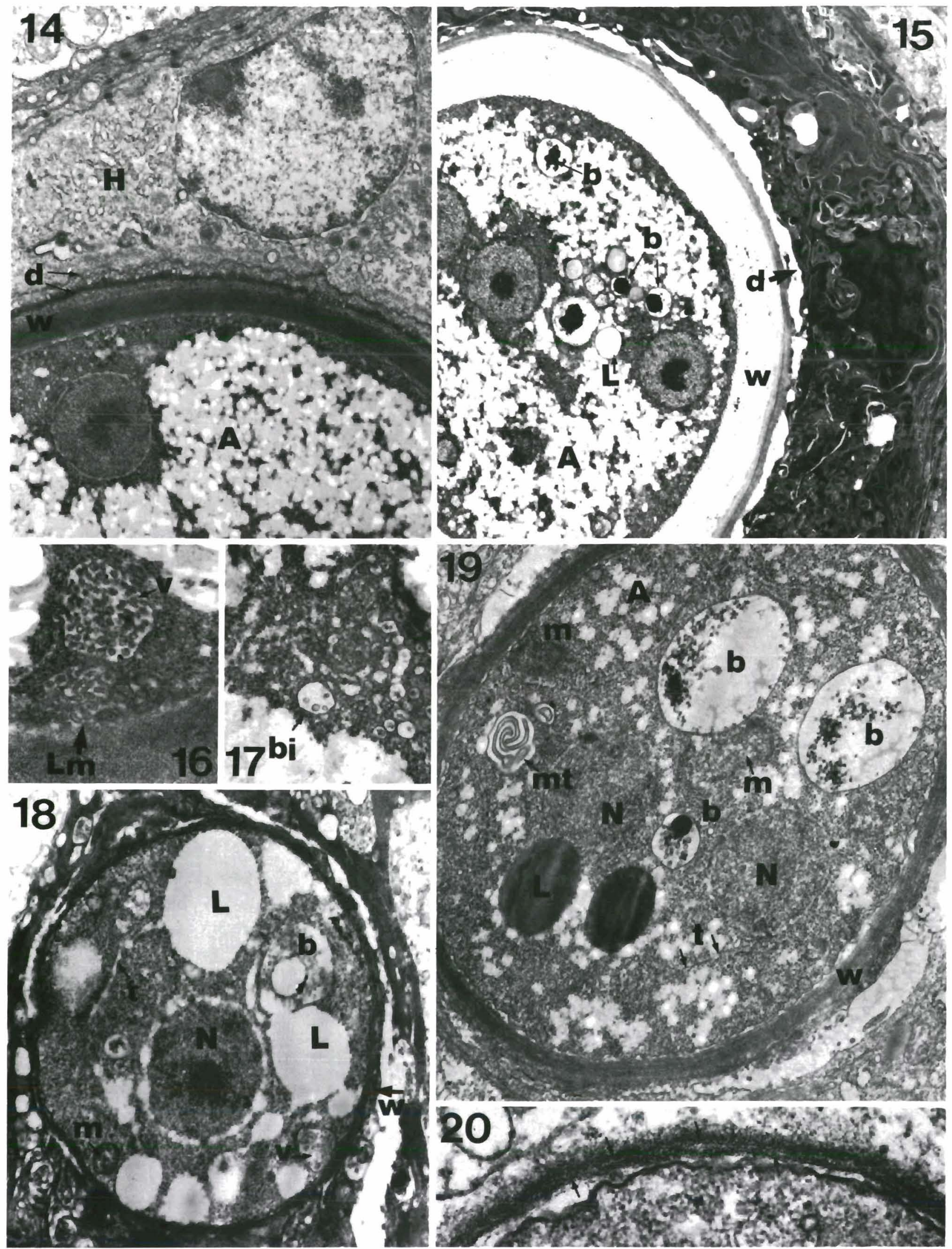

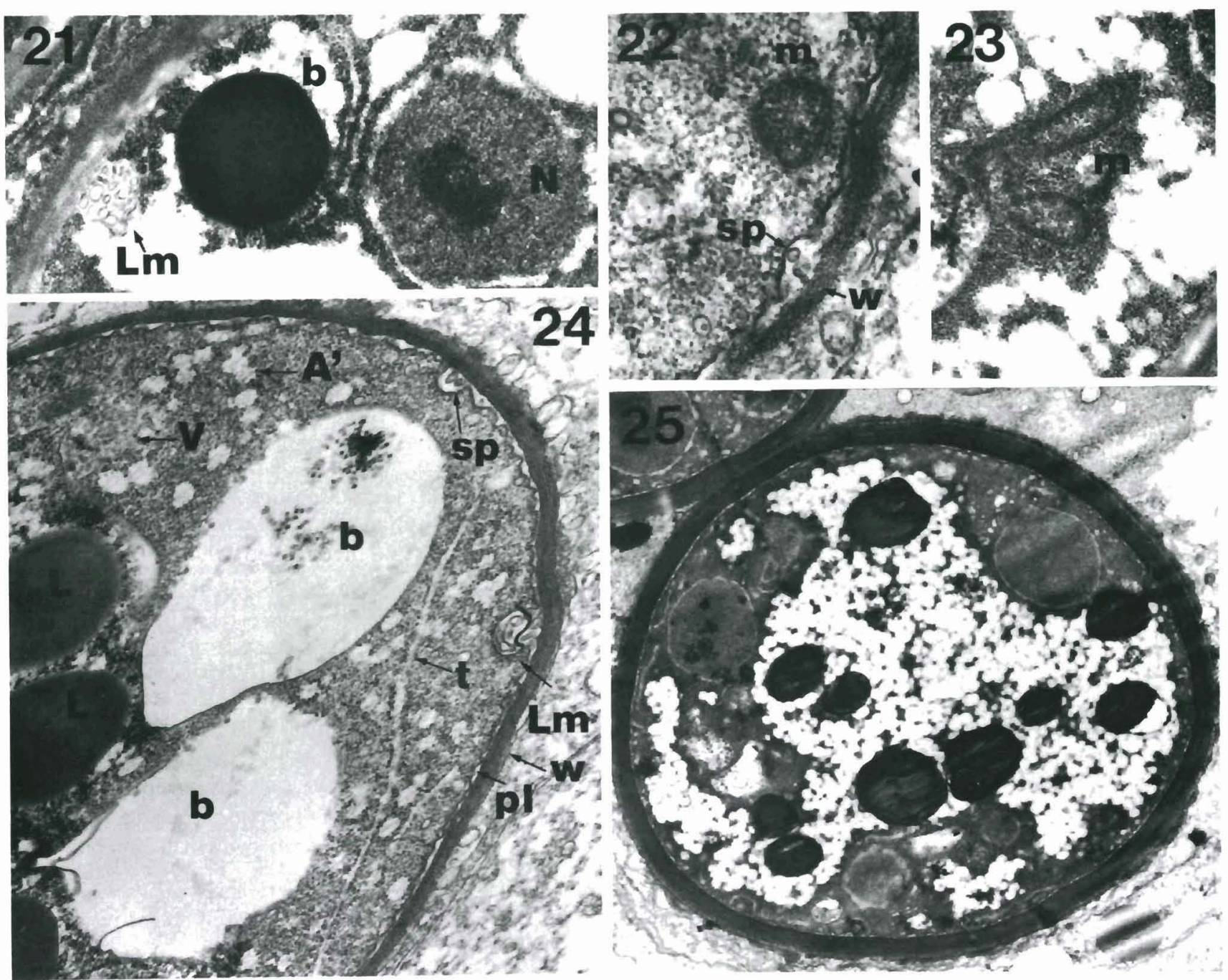

Fig. 21 to 25. Transmission electron micrographs. Fig. 21. Early S-spore: nucleus, dense body and lomasome $(\times 20,100)$. Fig. 22, 23. Early S-spore: mitochondria $(\times 42,400 ; \times 19,200)$. Fig. 24 . Binucleate S-spore: endoplasmic organelles and vacuoles $(\times 24,000)$. Fig. 25 . Differentiated young spore $(\times 9,570)$

red in the uninucleate and binucleate spores (Fig. 18 \& 19). The electron-lucent vacuoles appeared to be lipid vacuoles depleted from their substance. Similar large vacuoles, often found alongside the lipid ones, contained either electron-dense scattered material (Fig. 19 $\& 24$ ), or a consolidated dense body (Fig. 21). Dictyosomes were present in the endoplasm as well as endoplasmic tubuli and cisternae (Fig. 19 \& 24); lomasomes, multivesicular bodies and mitochondria (with tubular cristae) were readily traced, unlike in the M-spores (Fig. 21, $22 \& 23$ ).

\section{DISCUSSION}

The histopathological changes induced by Ichthyophonus infections in grey mullets generally conform to those described in previous reports (Ruggieri et al. 1970, Hendricks 1972). The photograph presented by Machado-Cruz et al. (1982) in their report on infection in grey mullets shows an encapsulated necrotic lesion which could have resulted from a variety of aethological factors.

Variations in the type and magnitude of the lesions

Fig. 14 to 20. Transmission electron micrographs. Fig. 14. Interface between M-spore and host tissue $(\times 11,300)$. Fig. 15. M-spore with degenerating wall, enclosed in dense layer of host cellular residue (d) $(\times 5,800)$. Fig. 16. Lomasome and multivesicular vacuole in the paramural endoplasm $(\times 27,300)$. Fig. 17 . Dictyosomes in the perinuclear endoplasm $(\times 16,900)$. Fig. 18. Early stage, uninucleate S-spore $(\times 16,700)$. Fig. 19. Binucleate S-spore $(\times 16,200)$. Fig. 20. Wall (arrows) and plasmalemma of early S- 
and in the induced host response are inevitable in infections which occur among different fish species with variable severity and pathogenic history. Giant cell reaction as reported by Timur \& Timur (1984) and McVicar \& McLay (1985), or syncytial formation of the epitheloid layer as reported by Miyazaki \& Kubota (1977), were not observed in the present study.

The aggregation of S-spores ('endospores') in the periphery of large M-spores ('resting spores') confirms earlier reports of secondary infection due to sporulation of the M-spores (Dorier \& Degrange 1961, McVicar 1982). Cleavage of multinucleate spores has only been seen in vitro, in culture conditions (Daniel 1933, Dorier \& Degrange 1961), or in host tissues, post mortem (McVicar 1982). In post mortem tissues and in culture, large multinucleate spores either sporulate endogenously or germinate hyphae before sporulation (Daniel 1933, Dorier \& Degrange 1961, McVicar 1982, Okamoto et al. 1985). Germination was observed in histological specimens (Hendricks 1972, present study). However, germination could result from delay in fixation of the tissue.

The fine structure of early and differentiated spore stages of Ichthyophonus evidence affinities with the fungi. All the organelles traced in the endoplasm could be identified with, or at least were structurally similar to, organelles of phycomycete fungi (Moore 1965, 1971, Heath \& Greenwood 1970, Gay et al. 1971, Emmons et al. 1977). The fine structural data presented here does not provide sufficient supportive evidence for affinities with any particular taxa of fungi. A search for affinities with specialised tissue inhabiting parasitic fungi (Emmons et al. 1977, Rippon 1982), does not provide additional clues. Ichthyophonus was distinctly different in its fine structure from Basidiobolus (as reported by Williams et al. 1969) to which it was earlier affiliated (Léger 1927). Okamoto et al. (1985) suggested a possible relation with the yeast-like fungi Blastomyces and Histoplasma which develop hyphae in culture; fine structural data (Dumont \& Piché 1969, Garrison et al. 1970), however, do not provide support to this suggestion. Some relation may exist with Rhinosporidium seeberi, as far as can be judged from the available fine structural data (Vanbreuseghen 1973). R. seeberi electron micrographs demonstrate a stage of development where the sporangium (possibly homologous with the 'resting spore' of Ichthyophonus) already cleaved into individual spores. This stage has not been studied ultrastructurally in Ichthyophonus. The spores with their single nucleus, dense bodies ('spherules') and laminated wall are reminiscent of early stage spores of Ichthyophonus. $R$. seeberi is, however, as enigmatic taxonomically as Ichthyophonus.

Electron micrographs of Ichthyophonus from in vitro culture (Okamoto et al. 1985) present the following changes: (a) dissolution of the thick fibrous wall which is gradually transformed into a structure comparable to those seen in non-parasitic phycomycete and deuteromycete fungi $i_{i}$ (b) dissolution of the dense bodies, while their electron-dense substance is fragmenting and dispersing into the endoplasm; (c) swelling of the dictyosomes, which become more reminiscent of the cisternal system which substitutes Golgi elements in many groups of fungi (Moore 1971). Structural changes between in vitro and in situ parasitic stages could suggest that at least part of the structural peculiarities of Ichthyophonus may result from convergent adaptation to parasitism.

Phagocytosis was described as a primary defence device of the host to invading spores (Dorier \& Degrange 1960, Miyazaki \& Kubota 1977, McVicar 1982). Although early stage spores were seen in the blood vessels, phagocytosis by macrophages might also be an effective mechanism for the dissemination of primary and secondary infections to the host organs. Histological data suggest primary location of spores in the connective tissue.

Electron micrographs of early spores suggest their intracellular location. Their growth leads to the destruction, firstly of the host cell and subsequently of adjacent host cells. Thus the primary pathological effect of infection is that of pressure atrophy. Residues of the surrounding host cells become incorporated into the spore wall during spore growth. Therefore, the chronic inflammatory changes, i.e. the granuloma, appears to be induced by the accumulation of cellular necrotic residue, rather than as a direct reaction to the parasite or its products. In the infected plaice the Langhans-type giant cells seen around the $\mathrm{M}$-spore in infected tissue of plaice (McVicar \& McLay 1985) appear to be active in the removal of host cell necrotic residues. This explains the absence of the superficial layer of host tissue residues on the spore wall in the electron micrographs presented from the infected plaice. The naked fibrous wall of the M-spore was in direct contact with cell wall of the active giant cell (McVicar \& McLay 1985).

Acknowledgements. This study was carried while the author was Hugh Kelly fellow in the department of Ichthyology and Fisheries Sciences, Rhodes University, Grahamstown, Republic of South Africa. I wish to thank Dr. T. Hecht, head of this department, and his staff for their cooperation, assistance and generous support with materials and facilities. The electron microscopy work was carried out in the Electron Microscopy Unit, R. U.; I thank R. H. M. Cross, director of the unit and A. $\mathrm{H}$. Hartly for their assistance and advice in the electron microscopic work. 


\section{LITERATURE CITED}

Alderman, D. J. (1982). Fungal diseases of aquatic animals. In: Roberts, R. J. (ed.) Microbial diseases of fish. Academic press, London, p. 189-242

Chien, C.-H., Miyazaki, T., Kubota, S. S. (1979). Studies on Ichthyophonus disease of fishes - IV. Comparative study on naturally infected fishes. Bull. Fac. Fish. Mie Univ. 6: $129-146$

Daniel, G. (1933). Studies on Ichthyophonus hoferi, a parasitic fungus of the herring, Clupea harengus. I. The parasite as it is found in the herring. Am. J. Hyg. 17: 262-276

Dorier, A., Degrange, C. H. (1961). L'evolution de l'Ichthyosporidium (Ichthyophonus) horeri (Plehn and Muslow) chez les salmonides d'élevage (truite arc-en-ciel et saumon de fontaine). Trav. Lab. Hydrobiol. Piscic. Univ. Grenoble 52: $7-44$

Dumont, A., Piché, C. (1969). Electron microscopic study of human histoplasmosis. Arch. Pathol. 87: 168-178

Emmons, C. W., Binford, C. H., Utz, J. P., Kwon-Chung K. J. (1977). Medical mycology, 3rd edn. Lea \& Febiger, Philadelphia, p. 1-592

Garrison, R. G., Lane, J. W., Field, M. F. (1970). Ultrastructural changes during the yeast-like to mycelial-phase conversion of Blastomyces dermatitidis and Histoplasma capsulatum. J. Bacteriol. 101: 628-635

Gay, J. L., Greenwood, A. D., Heath, I. B. (1971). The formation and behaviour of vacuoles (vesicles) during oosphere development and zoopore germination in Saprolegnia. J. gen. Microbiol. 65: 233-241

Gustafson, P. V., Rucker, R. R. (1956). Studies on an Ichthyosporidium infection in fish: transmission and host specificity. Spec. Scient. Rep. U.S. Fish Wildl. Serv. 166: 1-8

Heath, I. B., Greenwood, A. D. (1970). The structure and formation of lomasomes. J. gen. Microbiol. 62: 129-137

Hendricks, J. D. (1972). Two new host species for the parasitic fungus Ichthyophonus hoferi in the northwest Atlantic. J. Fish. Res. Bd Can. 29: 1776-1777

Léger, L. (1927). Sur la nature et l'evolution des 'Sphérules' décrite chez les Ichthyophonus, Phycomycètes parasite de la truite. C. r. hebd. Séanc. Acad. Sci., Paris 184: 1268-1271

Lulham, C. N. (1979). Glycol methacrylate embedding for light microscopy. J. Histotech. 2: 68-71

Machado-Cruz, J. C., Eiras, J. C., Marques, D. (1982). Two new hosts (Mugil auratus and Blenius pholis) of Ichthyosporeidiun and diagnosis in assimptomatic carrier. Publ. Inst. Zool. 'Dr. Augusto Nobre' Fac. Ciencias Porto 167: 5-11

McVicar, A. H. (1982). Ichthyophonus infection in fish. In: Roberts, R. J. (ed.) Microbial diseases of fish. Academic Press, London, p. 243-269

McVicar, A. H., McLay, H. A. (1985). Tissue response of plaice, haddock and rainbow trout to the systemic fungus Ichthyophonus. In: Ellis, A. E. (ed.) Fish and shellfish pathology. The Crown, p. 329-346

Miyazaki, T., Kubota, S. (1977). Studies on Ichthyophonus disease of fish - I. Rainbow trout fry. Bull. Fac. Fish. Mie Univ. 4: 45-56 (in Japanese)

Moore, R. T. (1965). The ultrastructure of fungal cells. In: Ainsworth, G. C., Sussman, A. S. (ed.) The fungi. Academic Press, New York, p. 95-118

Moore, R. T. (1971). An alternative concept of the fungi based on their ultrastructure. In: Perez-Miravete, A., Pelaez, D. (ed.) Recent advances in microbiology. X international Congress on Microbiology, Mexico D.F. Associacion Mexicana de Microbiologia, p. 49-64

Neish, G. A., Hughes, G. C. (1980). Fungal diseases of fishes. In: Snieszko, S. F., Axelrod, H. R. (ed.) Diseases of fishes. T.F.H. Publications, Neptune, New Jersey, Book 6, p. $1-159$

Okamoto, N., Nakase, K., Suzuki, H., Nakai, Y., Fujii, K., Sano, T. (1985). Life history and morphology of Ichthyophonus hoferi in vitro. Fish Path. 20: 273-285

Rippon, J. W. (1982). Medical mycology, 2nd edn. W. B. Saunders Comp. Philadelphia, p. 1-842

Ruggieri, G. D., Nigrelli, R. F., Powles, P. M., Garnett, D. G. (1970). Epizootics in yellowtail flounder, Limanda ferruginea Storer. in the western North Atlantic caused by Ichthyophonus, an ubiquitous parasitic fungus. Zoologica, N.Y. 55: 57-62

Timur, G., Timur, M. (1984). Giant-cell reaction associated with Ichthyophonus hoferi infection in wild plaice, Pleuronectes platessa L. J. Fish Dis. 7: 513-514

Vanbreuseghem, R. (1973). Ultrastructure of Rhinosporidium seeberi. Int. J. Dermatol. 12: 20-28

Williams, A., v. Lichtenberg, F., Smith, H., Martinson, F. D. (1969). Ultrastructure of phycomycosis. Arch. Pathol. 87: $459-468$ 